\title{
Studies on Integrated Nutrient Management (INM) Practices on Soil Characteristics and Yield in Tissue Culture Banana cv. Grand Naine (AAA)
}

\author{
S. Firoz Hussain ${ }^{1^{*}}$, Lakshminarayana Reddy ${ }^{2}$ and Venkata Ramudu $^{3}$ \\ ${ }^{1}$ Dr YSRHU, Venkataramannagudem, Andhra Pradesh, India \\ ${ }^{2}$ Department of Horticulture, Dr YSRHU, Venkataramannagudem, Andhra Pradesh, India \\ ${ }^{3}$ SKCHS, Anantapuramu, Andhra Pradesh, India \\ *Corresponding author
}

\begin{tabular}{|l|}
\hline Ke y w or d s \\
$\begin{array}{l}\text { INM, Tissue } \\
\text { culture, Banana and } \\
\text { Grand Naine. }\end{array}$ \\
\hline Article Info \\
\hline $\begin{array}{l}\text { Accepted: } \\
19 \text { October } 2017 \\
\text { Available Online: } \\
10 \text { December } 2017\end{array}$ \\
\hline
\end{tabular}

\section{A B S T R A C T}

A field study was undertaken at College of Horticulture, Anantharajupet during the years 2012 - 2013 to investigate the possible effects of different INM treatments on soil nutrient contents before planting and harvest, number of leaves emerged and yield and its attributes. The results revealed available nitrogen content in the experimental plots even before planting of the experiment was significantly differed and recorded higher available nitrogen content (215.39) in the plot allotted for $80 \%$ RDF (inorganic) $+20 \%$ RDN (FYM) along with Azosprillum + Phosphate solubilizing bacteria (PSB) + Frateuria aurantia (FA). Before planting of the experiment, available phosphorus content in the soil was significantly altered and significantly higher available phosphorus content in the soil was registered in the plot allotted for $100 \%$ RDF (inorganic). Available potassium content in the soil was significantly affected before planting of the experiment and significantly higher available potassium content in the soil was recorded in the plot allotted for $80 \%$ RDF (inorganic) $+20 \%$ RDN (FYM) + FA (450.83 kg ha $\left.{ }^{-1}\right)$. Significantly higher available potassium content in the soil was registered in the $80 \% \mathrm{RDF}$ (inorganic) $+20 \% \mathrm{RDN}$ (VC) + Azospirillum, PSB and FA (276.51 $\left.\mathrm{kg} \mathrm{ha}^{-1}\right)$ treatment plot. At 5 MAP, plants supplied with $80 \%$ RDF (inorganic) + $20 \%$ RDN (FYM) along with Azospirillum, PSB and FA have put forth significantly maximum number of leaves (29.6). Application of 80 $\%$ RDF (inorganic) $+20 \%$ RDN (FYM) along with Azospirillum, PSB and FA has resulted in production of maximum leaves at shooting (37.8). Significantly maximum number of hands bunch ${ }^{-1}$ (10.75) was obtained with application of $80 \%$ RDF $+20 \%$ RDN through FYM + Azospirillum, PSB and FA and it was at par with application of $80 \% \mathrm{RDF}+20 \% \mathrm{RDN}$ through VC + Azospirillum, PSB and FA and $80 \% \mathrm{RDF}+$ $20 \%$ RDN through FYM + FA. Application of $80 \%$ RDF + 20\% RDN through FYM + Azospirillum, PSB and FA has recorded significantly higher number of fruits bunch ${ }^{-1}$ (156.50) and it was on a par with application of $80 \%$ RDF $+20 \%$ RDN through FYM and $80 \% \mathrm{RDF}+20 \% \mathrm{RDN}$ through VC + Azospirillum, PSB and FA. Significantly highest bunch weight $(24.53 \mathrm{~kg})$ was recorded with application of $80 \% \mathrm{RDF}+20 \%$ RDN through FYM + Azospirillum, PSB and FA and it was on a par with application of $80 \% \mathrm{RDF}+20 \% \mathrm{RDN}$ through $\mathrm{VC}+$ Azospirillum, $\mathrm{PSB}$ and $\mathrm{FA}$ and $80 \% \mathrm{RDF}+$ $20 \%$ RDN through VC + FA 


\section{Introduction}

By nature, banana is a heavy consumer of nutrients and requires large quantities of nutrients for its growth, development and yield (Hazarika and Ansari, 2010). The requirements of these nutrients are generally supplied by inorganic fertilizers. But this often results in extremes situations for the soil, crop and climate involved. The soil has lost its biological dynamic owing to repeated and indiscriminate use of chemical fertilizer.

Chemical fertilizers have some deleterious effects on fruit quality besides adverse effects on soil, water and environmental conditions (Dutta et al., 2010). On the other hand, organic and microbial sources of nutrients have advantage of consistent and slow release of nutrients, maintaining ideal $\mathrm{C}$ : $\mathrm{N}$ ratio, improving water holding capacity and microbial biomass of soil profile, without any adverse residual effects (Yadav et al., 2010). It is estimated that 50 tonnes of banana in one hectare removes $320 \mathrm{~kg} \mathrm{~N}, 32 \mathrm{~kg} \mathrm{P}_{2} \mathrm{O}_{5}$ and $925 \mathrm{~kg} \mathrm{~K}_{2} \mathrm{O}$ every year (Lahav and Turner, 1983). Application of inorganic fertilizers though increases the yield substantially but could not able to sustain the fertility status of the soil (Bharadwaj and Omanwar, 1994) and have caused several undesirable consequences in the fragile eco-system, leading to gradual decline in productivity. Considering the present situation of soil quality and environmental security, it is necessary to go for an integrated nutrient management, involving various sources of organic manures and biofertilizers besides using chemical fertilizers in banana. Integrated nutrient management in banana are being practiced and experimented in various parts of India.

The utility of microbes in maintenance and built up of soil fertility, thereby, enhancing plant growth and yield is indispensable (Marathe et al., 2011). Although chemical fertilizers contribute a lot in fulfilling the nutrient requirement but their regular, excessive and unbalanced use may lead to health and ecological hazards, depletion of physico-chemical properties of the soil and ultimately poor crop yields (Singh and Singh, 2009). Hence, there is an urgent need to think of alternate source of safe fertilizers which may enhance crop yields without having adverse effects on soil properties. Thus, the use of biofertilizers seems to be array of hope in this direction. Biofertilizers have been considered cheap, eco-friendly way of improving soil fertility status. Biofertilizers like Azospirillum have also been found to promote synthesis of growth promoting substances like auxins, gibberellins, and cytokinins (Awasthi et al., 1998). $\mathrm{N}$ - fixing bacteria possess unique potential of fixing atmospheric nitrogen either by living symbiotically or non - symbiotically or to transform native soil nutrients, from non usable form to usable form through biological process (Marwaha, 1995).

The organic manures and biofertilizers help in better utilization of added inorganic fertilizers thus reduce its level of application as well as reduce the deleterious effect of harsh chemical residues that the inorganic fertilizers leave in the soil (Umar, 2007). A judicious use of organic manures and biofertilizers may be effective not only in sustaining crop productivity and in soil health, but also in supplementing chemical fertilizers of the crops (Jaipaul et al., 2011). Integrated nutrient management (INM) found to be beneficial for maintenance of soil fertility and plant nutrient supply to an optimum level, for sustaining desired crop productivity through optimization of benefits from all possible sources of plant nutrients in an integrated manner. The basic principle of INM is the maintenance of soil fertility, sustainable agricultural productivity and improving farmers profitability through judicious and 
efficient use of chemical fertilizers, organic manure and biofertilizers etc (Bhalerao et al., 2009).

\section{Materials and Methods}

The present investigation was carried out during the years $2012-13$ at College of Horticulture, Anantharajupet which is located at an altitude of 215 meters above mean sea level at $13.98^{0}$ North latitude and $79.40^{\circ}$ East longitude, respectively. The maximum and minimum temperatures during the experiment were $39.03^{\circ} \mathrm{C}$ and $31.0^{\circ} \mathrm{C}$ and relative humidity during the period of crop growth ranged between 77.0 to $87.0 \%$ respectively. The experiment consisted of eleven treatments which were replicated thrice and the statistical design used was Randomized Block Design (RBD).

The treatments included were $\mathrm{T}_{1}-100 \%$ Recommended dose of fertilizers (RDF) 300:50:300 g NPK plant $^{-1}$ crop cycle $^{-1}, \mathrm{~T}_{2}$ $80 \%$ RDF 240:40:240 g NPK plant ${ }^{-1}$ crop cycle $^{-1}$ through inorganic fertilizers $+20 \%$ RDN through vermicompost (VC), $\mathrm{T}_{3}-80 \%$ RDF through inorganic fertilizers $+20 \%$ RDN through $\mathrm{VC}+$ Azospirillum, $\mathrm{T}_{4}-80 \%$ RDF through inorganic fertilizers $+20 \%$ $\mathrm{RDN}$ through $\mathrm{VC}+$ Phosphate solubilizing bacteria (PSB), $\mathrm{T}_{5}-80 \% \mathrm{RDF}$ through inorganic fertilizers $+20 \%$ RDN through VC + Frateuria aurantia (FA), $\mathrm{T}_{6}-80 \% \mathrm{RDF}$ through inorganic fertilizers $+20 \%$ RDN through $\mathrm{VC}+$ Azospirillum $+\mathrm{PSB}+\mathrm{FA}, \mathrm{T}_{7}-$ $80 \%$ RDF through inorganic fertilizers +20 $\%$ RDN (Farmyard manure (FYM), $\mathrm{T}_{8}-80 \%$ RDF through inorganic fertilizers $+20 \%$ $\mathrm{RDN}(\mathrm{FYM})+$ Azospirillum, $\mathrm{T}_{9}-80 \% \mathrm{RDF}$ through inorganic fertilizers $+20 \% \mathrm{RDN}$ $(\mathrm{FYM})+\mathrm{PSB}, \mathrm{T}_{10}-80 \% \mathrm{RDF}$ through inorganic fertilizers $+20 \%$ RDN (FYM) + $\mathrm{FA}$ and $\mathrm{T}_{11}-80 \% \mathrm{RDF}$ through inorganic fertilizers + $20 \%$ RDN (FYM) + Azospirillum + PSB + FA.
Calculated quantities of organic manures (Vermicompost @ 4.285 kg plant ${ }^{-1}$ and Farmyard manure @ $5.309 \mathrm{~kg} \mathrm{plant}^{-1}$ ) along with biofertilizers viz., Azospirillum (50 g), Phosphate solubilizing bacteria (50 g) and Frateuria aurantia (25 g) were applied directly to the pits prior to planting. Soil samples were collected before planting of banana seedlings and after the plant crop. Soil samples were analyzed for the physicochemical characters. The data was analyzed as per the method of variance outlined by Panse and Sukhatme (1985). Statistical significance was tested by $F$ value at $5 \%$ level of significance. Critical difference at 0.05 levels was worked out for the effects which were significant.

\section{Results and Discussion}

\section{Soil nutrient (available) status (kg ha ${ }^{-1}$ )}

\section{Nitrogen}

Available nitrogen content in the experimental plots even before planting of the experiment was significantly differed and recorded higher available nitrogen content (215.39) in the plot allotted for $80 \% \mathrm{RDF}$ (inorganic) $+20 \% \mathrm{RDN}(\mathrm{FYM})$ along with Azosprillum + PSB +FA (Table 3).

It was observed there is a gradual exhaustion of nutrients (nitrogen) in all the treatmental plots at harvest when compared to the initial fertility status of experimental plots. The depletion of nitrogen was less in the plots that received different INM treatments than the plots that received $100 \%$ RDF through inorganic fertilizers alone. It has been reported that combined use of organic and inorganic nutrient sources may influence the forms and availability of nitrogen through the process of mineralization and also act as store house of nutrients. Similar results were in concurrence with Selvamani and Manivannan 
(2009) and Hazarika et al., (2011) in banana cv. Grand Naine.

\section{Phosphorus}

Before planting of the experiment, available phosphorus content in the soil was significantly altered and significantly higher available phosphorus content in the soil was registered in the plot allotted for $100 \% \mathrm{RDF}$ (inorganic). However, available phosphorus content in the soil did not differ significantly after harvest of the crop (Table 3).

The dynamic changes of available phosphorus in soil before and after the plant crop can be attributed to beneficial influence of inoculated PSB. The organic manures themselves might have also contributed phosphorus to the nutrient pool. These results were in agreement with the findings of Srivastava (1998).

\section{Potassium}

It was conspicuous from Table 3 that available potassium content in the soil was significantly affected before planting of the experiment and significantly higher available potassium content in the soil was recorded in the plot allotted for $80 \% \mathrm{RDF}$ (inorganic) + $20 \%$ RDN (FYM) + FA (450.83 kg ha $\left.{ }^{-1}\right)$. Significantly higher available potassium content in the soil was registered in the $80 \%$ $\mathrm{RDF}$ (inorganic) + $20 \% \mathrm{RDN}(\mathrm{VC})+$ Azospirillum, PSB and FA (276.51 kg ha $\left.{ }^{-1}\right)$ treatment plot.

Table.1 Nutrient concentrations of organic manures and their quantities used in the investigation

\begin{tabular}{|l|l|c|c|l|l|}
\hline \multirow{2}{*}{ Organic manure } & \multicolumn{2}{|l|}{$\begin{array}{l}\text { Nurtient } \\
\text { concentration (\%) }\end{array}$} & Moisture (\%) & $\begin{array}{l}\text { Quantity applied (kg } \\
\text { plant }^{-1} \text { crop cycle }^{-1} \text { ) }\end{array}$ \\
\cline { 2 - 6 } & $\mathrm{N}$ & $\mathrm{P}$ & $\mathrm{K}$ & & \\
\hline Vermicompost & 1.40 & 0.33 & 0.90 & 37.2 & $4.285 \mathrm{~kg} \mathrm{plant}^{-1}$ \\
\hline FYM & 1.63 & 0.28 & 0.76 & 25.2 & $5.309 \mathrm{~kg} \mathrm{plant}^{-1}$ \\
\hline
\end{tabular}

Table.2 Physico - chemical properties of experimental site

A. Chemical composition

\begin{tabular}{|l|l|l|}
\hline Properties & Characterization & Method of analysis \\
\hline Soil $\mathrm{pH}$ & 7.58 & Glass electrode pH meter model 335 (Jackson, 1973) \\
\hline Electrical conductivity $\left(\mathrm{dSm}^{-1}\right)$ & 0.232 & Conductivity Bridge ELICO Model EM 88 (Jackson, 1973) \\
\hline Available Nitrogen $\left(\mathrm{Kg} \mathrm{ha}^{-1}\right)$ & 204.30 & Alkaline permanganate method (Subbaiah and Asija, 1956) \\
\hline $\begin{array}{l}\text { Available Phosphorus }\left(\mathrm{P}_{2} \mathrm{O}_{5}\right) \\
\left(\mathrm{Kg} \mathrm{ha}^{-1}\right)\end{array}$ & 18.84 & Olsen's method (Olsen et al., 1954) \\
\hline $\begin{array}{l}\text { Available potassium }\left(\mathrm{K}_{2} \mathrm{O}\right) \\
\left(\mathrm{Kg} \mathrm{h}^{-1}\right)\end{array}$ & 395.0 & $\begin{array}{l}\text { Neutral normal Ammonium Acetate method using Flame } \\
\text { Photometer (Muhr, 1965) }\end{array}$ \\
\hline
\end{tabular}

B. Physical composition

\begin{tabular}{|l|c|c|}
\hline Properties & Characterization & Method of analysis \\
\hline Sand $(\%)$ & 70 & \multirow{2}{*}{ International pipette method (Piper, 1966) } \\
\cline { 1 - 2 } Silt $(\%)$ & 10 & \\
\hline Clay $(\%)$ & 20 & \\
\hline Textural class & Sandy loam & \\
\hline
\end{tabular}


Table.3 Influence of different INM treatments on available soil nutrient status of Experimental plots

\begin{tabular}{|c|c|c|c|c|c|c|c|}
\hline \multirow[t]{2}{*}{ Treatments } & \multicolumn{2}{|c|}{ Available N $\left(\mathrm{Kg} \mathrm{ha}^{-1}\right)$} & \multicolumn{2}{|c|}{ Available P $\left(\mathrm{Kg} \mathrm{ha}^{-1}\right)$} & \multicolumn{3}{|c|}{ Available K $\left(\mathrm{Kg} \mathrm{ha}^{-1}\right)$} \\
\hline & $\begin{array}{c}\text { Before } \\
\text { planting }\end{array}$ & $\begin{array}{c}\text { After } \\
\text { harvest }\end{array}$ & $\begin{array}{c}\text { Before } \\
\text { planting }\end{array}$ & After harvest & $\begin{array}{c}\text { Before } \\
\text { planting }\end{array}$ & After harvest & \\
\hline $\mathbf{T}_{\mathbf{1}}: 100 \% \mathrm{RDF}$ & 204.04 & 166.23 & 28.35 & 15.60 & 369.17 & 239.36 & \\
\hline $\begin{array}{l}\mathbf{T}_{2}: 80 \% \mathrm{RDF}+20 \% \\
\text { RDN through VC }\end{array}$ & 206.07 & 178.77 & 19.76 & 15.19 & 325.00 & 210.00 & \\
\hline $\mathbf{T}_{\mathbf{3}}: \mathrm{T}_{2}+$ Azospirillum & 215.38 & 180.76 & 20.16 & 14.59 & 390.00 & 260.26 & \\
\hline $\mathbf{T}_{4}: \mathrm{T}_{2}+\mathrm{PSB}$ & 199.88 & 174.04 & 23.52 & 15.98 & 323.33 & 260.96 & \\
\hline $\mathbf{T}_{\mathbf{5}}: \mathrm{T}_{2}+\mathrm{FA}$ & 209.13 & 179.34 & 18.92 & 15.00 & 417.50 & 269.17 & \\
\hline $\begin{array}{l}\mathbf{T}_{\mathbf{6}}: \mathrm{T}_{2}+\text { Azospirillum }+ \\
\text { PSB + FA }\end{array}$ & 195.97 & 173.86 & 19.26 & 15.00 & 431.67 & 276.51 & \\
\hline $\begin{array}{l}\mathbf{T}_{7}: 80 \% \mathrm{RDF}+20 \% \\
\mathrm{RDN} \text { through }+\mathrm{FYM}\end{array}$ & 214.04 & 181.10 & 19.59 & 15.10 & 379.17 & 224.32 & \\
\hline $\mathbf{T}_{\mathbf{8}}: \mathrm{T}_{7}+$ Azospirillum & 203.55 & 182.72 & 16.46 & 16.00 & 390.00 & 234.08 & \\
\hline $\mathbf{T}_{\mathbf{9}}: \mathrm{T}_{7}+\mathrm{PSB}$ & 197.13 & 165.62 & 21.48 & 17.04 & 369.17 & 227.35 & \\
\hline $\mathbf{T}_{10}: \mathrm{T}_{7}+\mathrm{FA}$ & 204.11 & 172.50 & 19.36 & 14.08 & 450.83 & 261.09 & \\
\hline $\begin{array}{l}\mathbf{T}_{11}: \mathrm{T}_{7}+\text { Azospirillum } \\
+ \text { PSB + FA }\end{array}$ & 198.10 & 197.74 & 24.19 & 16.54 & 367.50 & 271.36 & \\
\hline Mean & 204.30 & 177.51 & 21.00 & 15.46 & 383.03 & 248.58 & \\
\hline S.Em. $( \pm)$ & 3.47 & 5.05 & 1.24 & 1.25 & 19.6 & 8.00 & \\
\hline C.D. $(P=0.05)$ & 10.32 & 15.01 & 3.70 & N.S. & 58.31 & 23.75 & \\
\hline
\end{tabular}

RDF: Recommended dose of fertilizers, RDN: Recommended dose of nitrogen, PSB: Phosphate solubilizing bacteria, FA: Frateuria aurantia

Table.4 Total number of leaves emerged plant $^{-1}$ at various stages of crop growth as influenced by different INM practices

\begin{tabular}{|c|c|c|c|}
\hline \multirow[t]{2}{*}{ Treatments } & \multicolumn{3}{|c|}{ Total number of leaves emerged plant ${ }^{-1}$ crop cycle ${ }^{-1}$} \\
\hline & 3 MAP & 5 MAP & Shooting \\
\hline $\mathbf{T}_{\mathbf{1}}: 100 \% \mathrm{RDF}$ & 17.9 & 26.7 & 34.7 \\
\hline $\begin{array}{l}\mathbf{T}_{2}: 80 \% \mathrm{RDF}+20 \% \mathrm{RDN} \\
\text { through VC }\end{array}$ & 17.2 & 26.9 & 35.6 \\
\hline $\mathbf{T}_{3}: \mathrm{T}_{2}+$ Azospirillum & 17.7 & 26.8 & 36.3 \\
\hline $\mathbf{T}_{4}: \mathrm{T}_{2}+\mathrm{PSB}$ & 17.8 & 27.2 & 34.3 \\
\hline $\mathbf{T}_{\mathbf{5}}: \mathrm{T}_{2}+\mathrm{FA}$ & 18.8 & 27.6 & 36.7 \\
\hline $\begin{array}{l}\mathbf{T}_{6}: \mathrm{T}_{2}+\text { Azospirillum }+\mathrm{PSB}+ \\
\text { FA }\end{array}$ & 19.3 & 29.1 & 36.8 \\
\hline $\begin{array}{l}\mathbf{T}_{7}: 80 \% \mathrm{RDF}+20 \% \mathrm{RDN} \\
\text { through + FYM }\end{array}$ & 16.2 & 26.7 & 34.1 \\
\hline $\mathbf{T}_{8}: \mathrm{T}_{7}+$ Azospirillum & 17.7 & 28.0 & 33.8 \\
\hline $\mathbf{T}_{\mathbf{9}}: \mathrm{T}_{7}+\mathrm{PSB}$ & 18.3 & 27.8 & 35.3 \\
\hline $\mathbf{T}_{\mathbf{1 0}}: \mathrm{T}_{7}+\mathrm{FA}$ & 18.7 & 28.0 & 35.9 \\
\hline $\begin{array}{l}\mathbf{T}_{11}: \mathrm{T}_{7}+\text { Azospirillum }+ \text { PSB }+ \\
\text { FA }\end{array}$ & 20.2 & 29.6 & 37.8 \\
\hline Mean & 18.16 & 25.12 & 35.57 \\
\hline S.Em. $( \pm)$ & 0.73 & 0.50 & 0.22 \\
\hline C.D. $(P=0.05)$ & N.S. & 1.49 & 0.66 \\
\hline
\end{tabular}

RDF: Recommended dose of fertilizers, RDN: Recommended dose of nitrogen, PSB: Phosphate solubilizing bacteria, FA: Frateuria aurantia 
Table.5 Influence of different INM treatments on yield and its attributes in tissue culture banana cv. Grand Naine

\begin{tabular}{|c|c|c|c|c|c|c|}
\hline Treatments & $\begin{array}{l}\text { No. of hands } \\
\text { bunch }^{-1}\end{array}$ & $\begin{array}{l}\text { No. of fruits } \\
\text { bunch }^{-1}\end{array}$ & $\begin{array}{l}\text { Fruit } \\
\text { length } \\
(\mathrm{cm})\end{array}$ & $\begin{array}{l}\text { Fruit girth } \\
\qquad(\mathrm{cm})\end{array}$ & $\begin{array}{c}\text { Bunch } \\
\text { weight } \\
\text { (kg) }\end{array}$ & $\begin{array}{c}\text { Yield } \\
\left(\mathbf{t ~ h a} \mathbf{~ h}^{-1}\right)\end{array}$ \\
\hline $\mathbf{T}_{\mathbf{1}}: 100 \% \mathrm{RDF}$ & 8.91 & 136.58 & 21.73 & 13.16 & 19.35 & 53.65 \\
\hline $\begin{array}{l}\mathbf{T}_{\mathbf{2}}: 80 \% \mathrm{RDF}+20 \% \mathrm{RDN} \\
\text { through VC }\end{array}$ & 9.25 & 139.16 & 21.15 & 13.12 & 19.80 & 54.89 \\
\hline $\mathbf{T}_{3}: \mathbf{T}_{2}+$ Azospirillum & 9.16 & 144.58 & 21.65 & 13.41 & 20.91 & 57.97 \\
\hline $\mathbf{T}_{\mathbf{4}}: \mathrm{T}_{2}+\mathrm{PSB}$ & 9.41 & 145.41 & 22.50 & 13.25 & 22.00 & 60.99 \\
\hline $\mathbf{T}_{5}: \mathrm{T}_{2}+\mathrm{FA}$ & 9.50 & 144.33 & 22.25 & 12.94 & 23.50 & 65.15 \\
\hline $\begin{array}{l}\mathbf{T}_{\mathbf{6}}: \mathrm{T}_{2}+\text { Azospirillum }+ \text { PSB }+ \\
\text { FA }\end{array}$ & 10.33 & 150.08 & 24.33 & 14.25 & 23.92 & 66.31 \\
\hline $\begin{array}{l}\mathbf{T}_{7}: 80 \% \mathrm{RDF}+20 \% \mathrm{RDN} \\
\text { through + FYM }\end{array}$ & 9.16 & 150.25 & 23.39 & 13.87 & 21.50 & 59.61 \\
\hline $\mathbf{T}_{8}: \mathrm{T}_{7}+$ Azospirillum & 9.25 & 137.00 & 22.20 & 13.34 & 20.40 & 56.57 \\
\hline $\mathbf{T}_{\mathbf{9}}: \mathrm{T}_{7}+\mathrm{PSB}$ & 8.83 & 138.41 & 22.42 & 13.00 & 19.75 & 54.76 \\
\hline $\mathbf{T}_{10}: \mathrm{T}_{7}+\mathrm{FA}$ & 10.00 & 141.66 & 22.79 & 13.98 & 21.41 & 59.36 \\
\hline $\begin{array}{l}\mathbf{T}_{11}: \mathrm{T}_{7}+\text { Azospirillum }+ \text { PSB } \\
+\mathrm{FA}\end{array}$ & 10.75 & 156.50 & 23.12 & 14.37 & 24.53 & 68.02 \\
\hline Mean & 9.50 & 143.99 & 22.50 & 13.51 & 21.55 & 59.75 \\
\hline S.Em. $( \pm)$ & 0.30 & 2.90 & 0.55 & 0.28 & 0.83 & 2.29 \\
\hline C.D. $(P=0.05)$ & 0.91 & 8.62 & 1.62 & 0.84 & 2.46 & 6.81 \\
\hline
\end{tabular}

RDF: Recommended dose of fertilizers, RDN: Recommended dose of nitrogen, PSB: Phosphate solubilizing bacteria, FA: Frateuria aurantia

There is a gradual decline of potassium levels in all the treatmental plots at harvest when compared to the plots allotted for treatment application prior to planting. Plots that received $80 \% \mathrm{RDF}$ (inorganic) along with supply of $20 \%$ RDF either through vermicompost or FYM and Frateuria aurantia has exhibited less depletion of potassium over its initial status.

Santhy et al., (1999) observed the role of organic manures associated with minimizing the losses from leaching by retaining $\mathrm{K}$ - ions on exchange sites. Further, Frateuria aurantia has a role of releasing potassium from clay minerals by shifting the equilibrium between soluble and insoluble forms (Alexander, 1985). This is a positive indication that inclusion of Frateuria aurantia as one of the component in the INM package to obtain beneficial influence on soil potassium results.

\section{Total number of leaves emerged plant ${ }^{-1}$}

Total number of leaves emerged plant $^{-1}$ was significantly influenced at each crop stage by different treatments except at 3 MAP (Table 4). At $5 \mathrm{MAP}$, plants supplied with $80 \% \mathrm{RDF}$ (inorganic) $+20 \%$ RDN (FYM) along with Azospirillum, PSB and FA have put forth significantly maximum number of leaves (29.6). Application of $80 \%$ RDF (inorganic) $+20 \%$ RDN (FYM) along with Azospirillum, PSB and FA has resulted in production of maximum leaves at shooting (37.8).

The total number of leaves emerged in a plant crop are in a range of 35 to 46 as prescribed 
by Stover, 1979 for Grand Naine banana in tropics and this can be explained by the role of biofertilizers (Azospirillum, PSB and Frateuria aurantia) and organic manures such as vermicompost and farmyard manure might have improved the soil physical condition required for plant growth and it also could be due to increased availability of nutrients especially nitrogen as it has a prominent role in leaf emission (Murray, 1960).

\section{Yield characters}

Data presented in Table 5 indicates that significant differences were observed with regard to yield and its attributes viz., number of hands bunch ${ }^{-1}$, fruits bunch ${ }^{-1}$, bunch weight and fruit yield due to different treatments.

Significantly maximum number of hands bunch $^{-1}$ (10.75) was obtained with application of $80 \% \mathrm{RDF}+20 \% \mathrm{RDN}$ through FYM + Azospirillum, PSB and FA and it was at par with application of $80 \% \mathrm{RDF}+20 \% \mathrm{RDN}$ through VC + Azospirillum, PSB and FA and $80 \%$ RDF + 20\% RDN through FYM + FA.

Application of $80 \% \mathrm{RDF}+20 \% \mathrm{RDN}$ through FYM + Azospirillum, PSB and FA has recorded significantly higher number of fruits bunch ${ }^{-1}$ (156.50) and it was on a par with application of $80 \% \mathrm{RDF}+20 \% \mathrm{RDN}$ through FYM and $80 \% \mathrm{RDF}+20 \% \mathrm{RDN}$ through $\mathrm{VC}+$ Azospirillum, PSB and FA.

Significantly highest bunch weight $(24.53 \mathrm{~kg})$ was recorded with application of $80 \% \mathrm{RDF}+$ $20 \%$ RDN through FYM + Azospirillum, PSB and FA and it was on a par with application of $80 \% \mathrm{RDF}+20 \%$ RDN through $\mathrm{VC}+$ Azospirillum, PSB and FA and $80 \% \mathrm{RDF}+$ $20 \%$ RDN through VC + FA.

The increase in bunch weight was associated with corresponding increase in number of hands bunch ${ }^{-1}$, fruits bunch ${ }^{-1}$, fruit girth which were found to be highest in treatment $80 \%$ $\mathrm{RDF}+20 \%$ RDN through FYM + Azospirillum, PSB, FA plant ${ }^{-1}$ were in accordance with the findings of Tejinder and Dhaliwal (2009).

\section{References}

Alexander, M. 1985. In Introduction to Microbiology. $3^{\text {rd }}$ edn. Willey Eastern Ltd. New Delhi.

Awasthi, R.P., Godara, R.K. and Kaith, N.S. 1998. Interaction effect of VA mycorrhizae and Azotobacter inoculation on micronutrient uptake by peach seedlings. Journal of Horticulture. 11: 15.

Bhalerao, V.P, Patil, N.M, Badgujar, C.D. and Patil, D.R. 2009. Studies on Integrated Nutrient Management for tissue culture Grand Naine banana. Indian Journal of Agriculture Research. 43(2): 107-112.

Bharadwaj, V. and Omanwar, P.K. 1994. Long term effects of continuous rotational cropping and fertilization on crop yields and soil properties - II. Effects on EC, $\mathrm{pH}$, organic matter and available nutrients of soil. J. Indian Soc. Soil Sci., 42(3): 387-392.

Dutta, P, Kundu, S and Biswas, S. 2010. Integrated nutrient management in litchi cv. Bombai in new alluvial zone of West Bengal. Indian Journal of Horticulture. 67: 181-184.

Hazarika, B.N. and Ansari, S. 2010. Effect of Integrated Nutrient Management on growth and yield of banana cv. Jahaji (AAA). Indian Journal of Horticulture. 67: 270-273.

Hazarika, T.K., Nautiyal, B.P. and Bhattacharya. R.K. 2011. Effect of INM on productivity and soil characteristics of tissue cultured banana cv. Grand Naine in Mizoram, India. Progressive Horticulture. 43: 30-35.

Jackson, M.L. 1973. Soil chemical analysis. Prentice Hall of India. Pvt. Ltd, New Delhi. 
Jaipaul, Sharma, S, Dixit, A.K. and Sharma, A.K. 2011. Growth and yield of capsicum (Capsicum annum) and garden pea (Pisum sativum) as influenced by organic manures and biofertilizers. Indian Journal of Agricultural Sciences. 81(7): 637-642.

Lahav and Turner D.W. 1983. Banana nutrition bulletin No.7. International Potash Institute, Worblaufen-Bern, Switzerland.

Marathe, R.A, Chandra Ram, Maity, A, Sharma, J. and Jadhav, V.T. 2011. Effect of different microbial inoculants on soil properties nutrient acquisition and growth of pomegranate (Punica granatum). Indian Journal of Agricultural Sciences. 81(7): 622-627.

Marwaha, B.C. 1995. Biofertilizers - A, supplementary source of plant nutrients. Fertilizer news. 40: 39-50.

Muhr, G.R. 1965. Soil testing in India, USAID, New Delhi, India. Pp. 120.

Murray, D.B. 1960. The effects of deficiencies of major nutrients on growth and leaf analysis of the banana. Tropical Agriculture, Trinidad. 37: 97-106.

Olsen, S.R. 1954. Estimation of available phosphorus in soils by extraction with sodium bicarbonate. US Gov. Print Office, Washington, USA (USDA Circular No. 939).

Panse, V.G. and Sukhatme, P.V. 1985. Statistical Methods for Agricultural Workers. ICAR, New Delhi.

Piper, C.S. 1966. Soil and Plant Analysis. Hans Publisher, Bombay.

Santhy, P, Velusamy, M.S., Murugappan, V. and Selvi, D. 1999. Effect of inorganic fertilizers and fertilizer manure combination on soil physico-chemical properties and dynamics of microbial biomass in an inceptisol. J. Indian Soc.
Soil. Sci. 47: 479-482.

Selvamani, P. and Manivannan. K. 2009. Effect of organic manures, inorganic fertilizers and biofertilizers on the nutrient concentration in leaves at different growth stages of banana cv. Poovan. Journal of Phytology. 1(6): 381-387.

Singh, A. and Singh, J.N. 2009. Effect of biofertilizers and bioregulators on growth, yield and nutrient status of strawberry cv. Sweet Charlie. Indian Journal of Horticulture. 66: 220-224.

Srivastava, P. 1998. Integrated nutrient management for sustained fertility of soil. Indian Journal of Agricultural Chemists. XXXI: $1-2$.

Stover, R.H. 1971. A proposed international scale for estimating intensity of banana leaf spot (Mycosphaerella musicola Leach). Tropical Agriculture (Trinidad) 48: 185-196.

Subbaiah, B.V. and Asija, G.L. 1956. A rapid procedure for the determination of available nitrogen in the soils. 25: 259260.

Tejinder, Kaur, M.I.S. Gill and U.S. Dhaliwal. 2009. Effect of different levels of $\mathrm{N}$ and $\mathrm{P}$ on ratoon crop of banana cv. Grand Naine. Journal of Horticultural Sciences. 4(1): 68-70.

Umar, I. 2007. Studies on integrated nutrient management in strawberry (Fragaria $\mathrm{x}$ ananassa Duch.) cultivar Chandler. $\mathrm{PhD}$ thesis, S K University of Agricultural Sciences and Technology of Jammu, Udheywalla, Jammu, J \& K.

Yadav, S.K. Khokkhar, U.U. and Yadav, R.P. 2010. Integrated nutrient management for strawberry cultivation. Indian J. Hort. 67: 445-449.

\section{How to cite this article:}

Firoz Hussain, S., Lakshminarayana Reddy and Venkata Ramudu. 2017. Studies on Integrated Nutrient Management (INM) Practices on Soil Characteristics and Yield in Tissue Culture Banana cv. Grand Naine (AAA). Int.J.Curr.Microbiol.App.Sci. 6(12): 2557-2564.

doi: https://doi.org/10.20546/ijcmas.2017.612.296 